\title{
Clomazone Aktif Maddesinin Yarı Kurak Koşullarda Geleneksel Pamuk (Gossypium hirsutum L.) Tarlalarında Yabancı Ot Kontrolünde Çıkış Öncesi Herbisitlerle Tank Karışımı
}

\author{
Firat Pala ${ }^{1 *}$, Hüsrev Mennan ${ }^{2}$ \\ ${ }^{1}$ Siir Üniversitesi, Ziraat Fakültesi, Bitki Koruma Bölümü, İstanbul, Türkiye (ORCID: 0000-0002-4394-8841) \\ 2 Ondokuz Mayıs Üniversitesi, Ziraat Fakültesi, Bitki Koruma Bölümü, İstanbul, Türkiye (ORCID: 0000-0002-1410-8114)
}

(İlk Geliş Tarihi 1 Aralık 2019 ve Kabul Tarihi 31 Aralık 2019)

(DOI: 10.31590/ejosat.658839)

\begin{abstract}
ATIF/REFERENCE: Pala, F. \& Mennan, H. (2019). Clomazone Aktif Maddesinin Yarı Kurak Koşullarda Geleneksel Pamuk (Gossypium hirsutum L.) Tarlalarında Yabancı Ot Kontrolünde Çıkış Öncesi Herbisitlerle Tank Karışımı. Avrupa Bilim ve Teknoloji Dergisi, (17), 1256-1262.
\end{abstract}

$\ddot{\mathbf{O z}}$

Başarılı pamuk üretiminin kritik bileşenlerinden biri, etkili yabani ot yönetimidir. Pamuk (Gossypium hirsutum L.), yabani otlarla yeterince rekabet edemediğinden, özellikle ilk altı haftada, bazı yabani ot türleri pamuk verimini önemli ölçüde azaltmaktadır. Ayrıca yabani otlar pamuk hasadını zorlaştırabilir ve lifini kirletebilir. Türkiye geleneksel pamuk üretiminde (toleranslı ve dayanıklı olmayan çeşitler) özellikle geniş yapraklı yabancı ot kontrolü için tercih edilen temel yöntem, ekim öncesi veya çıkış öncesi herbisitlerin kullanılmasıdır. Bununla birlikte, farklı çıkış öncesi herbisitlerin karışımlarının etkileri hakkında fazla bilgi bulunmadığından, bu çalışma, pamukta çıkış önceki bir karışım olarak uygulanan herbisitlerin etkinliğini ve seçiciliğini belirlemek için yürütülmüştür. Arazi denemeleri tesadüf blokları deneme desenine göre dört tekerrürlü olarak 11 farklı uygulama olacak şekilde tasarlanmıştır. Parseller 20 metrekare $(4 \mathrm{~m}$ x $5 \mathrm{~m})$ olarak kurulmuştur. Bu çalışmada herbisit uygulamaları 2015 yılında Diyarbakır'da gerçekleştirilmiş ve çift clomazone aktif maddesinin fluometuron, oxyfluorfen ve pendimethalin ile farklı dozlardaki karışımları kullanılmıştı. Clomazone 0.21 ha- 1 + fluometuron 1,5 1 ha-1, clomazone 0.21 ha- 1 + fluometuron 21 ha-1, clomazone 0.41 ha- $1+$ pendimethalin 1.51 ha-1 ve clomazone 0.31 ha- 1 + pendimethalin 21 ha-1 karışımın yabani ot kontrol etkinliğinin tam olduğu tespit edilmiştir. Bu sonuç, clomazone aktif maddesi ile yapılan herbisit karışımlarının çıkış öncesi uygulandığında yabancı ot control etkinliği arttığını göstermektedir. Oxyfluorfen karışımlarında ürün seçiciliği açısından en tehlikeli hasar gözlenmiştir. En yüksek pamuk verimleri (> $5 \mathrm{t} \mathrm{ha}^{-1}$ ) sirasiyla clomazone $0.301 \mathrm{ha}^{-1}+$ fluometuron $21 \mathrm{ha}^{-1}$ ve clomazone $0.21 \mathrm{ha}^{-1}+$ fluometuron $1.51 \mathrm{ha}^{-1}$ karışımlarının uygulanmasından elde edilmiştir.

Anahtar Kelimeler: Pamuk, Ekim öncesi, Çıkış öncesi, Herbisitler, Yabancı ot.

\section{Compatibility of the Clomazone Active Ingredient with Pre- emergence Herbicides to Weed Control in Conventional Cotton (Gossypium hirsutum L.) Fields in Semi-arid Conditions}

\begin{abstract}
One of the critical components of successful cotton production is effective weed management. Since cotton (Gossypium hirsutum L.) cannot compete sufficiently with weeds, especially in the first six weeks, a certain number of weeds significantly reduces cotton yield. In addition, weeds can make cotton harvest difficult and contaminate cotton fiber. The main preferred control method for broadleaf weeds in the conventional cotton of Turkey (non-tolerant and non-resistant varieties) is the use of pre-emergence herbicides. However,
\end{abstract}

*Sorumlu Yazar: Siir Üniversitesi, Ziraat Fakültesi, Bitki Koruma Bölümü, İstanbul, Türkiye, ORCID: 0000-0002-4394-8841, firatpala@ siirt.edu.tr 
since there is not much information about the effects of mixtures of different pre-planting herbicides, the aim of this study is to evaluate the efficacy and selectivity of herbicides applied as a pre-emergence mixture in cotton. The randomized complete block design (RCBD) with four replications and eleven treatments was used in the field experiment. The plots were established to 20 square meters $(4 \mathrm{~m} \times 5 \mathrm{~m})$. Herbicide applications in the study were carried out in Diyarbakir in 2015, and dual mixtures of clomazone,

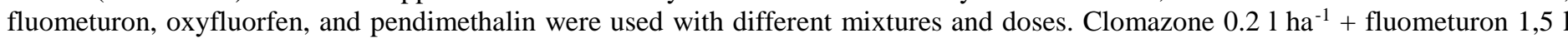

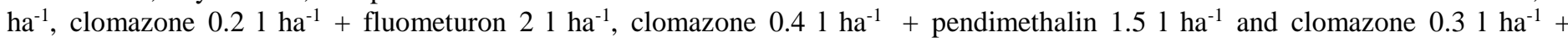
pendimethalin $21 \mathrm{ha}^{-1}$ mixture was found to be complete weed control efficiency. This result shows that mixtures with clomazone active ingredient increase in the efficiency of herbicides pre-planting. Oxyfluorfen mixtures showed the most hazardous damage in terms of product selectivity. The highest cotton yield $\left(>5 \mathrm{tha}^{-1}\right)$ was obtained from the application of mixes of clomazone 0.301 ha ${ }^{-1}$ + fluometuron $21 \mathrm{ha}^{-1}$ and clomazone $0.21 \mathrm{ha}^{-1}+$ fluometuron $1.51 \mathrm{ha}^{-1}$, respectively.

Keywords: Cotton, Pre-plant, Pre emergence, Herbicides, Weeds.

\section{Introduction}

Cotton (Gossypium hirsutum L.), an important industrial plant, is a slow-growing during the first germination period and cultivated as a one-year crop although it is actually a perennial plant (Ortiz and Bourland, 1999; EDIS, 2019). Often, the most competitive weeds germinate before or at the same time as cotton. In this case, cotton seedlings compete with weeds to reach sources such as water, nutrients, and sunlight for growth. Weed flora of a region varies according to soil type and environmental conditions. However, the dominant species that are often the problem in cotton cultivated areas are Amaranthus palmeri S. Wats., A. retroflexus L., Chenopodium album L., Convolvulus arvensis L., Cynodon dactylon (L.) Pers., Cyperus rotundus L., Echinochloa crus-galli (L.) P. Beauv., Hibiscus trionum L., Ipomoea purpurea (L.) Roth., Polygonum aviculare L., Setaria viridis (L.) P. Beauv., Solanum nigrum L., Sorghum halepense (L.) Pers., Tribulus terrestris L. and Xanthium strumarium L. (Zhang, 2003; Economou et al., 2005; Walker et al., 2005) Kruger et al., 2009; Memon et al., 2014; Pala and Mennan 2014; Berger et al., 2015; Kraehmer, 2015).

Therefore, the control of weeds in the first period is very effective for the competition of cotton. In general, planted cotton requires 9 and 11 weeks for a weed-free period (Papamichail et al., 2002; Bukun, 2004). Therefore, if weeds are not controlled in this period, it may cause a decrease cotton yield between 10-90\% (Berger et al., 2015; Nalini et al., 2015; Pala and Mennan, 2016). Weeds can also complicate harvesting and may interfere with the fiber as foreign matter, affecting fiber dyeing quality.

Effective early weed control in cotton maintains the yield potential of the crop. Pre-planting or pre-emergence herbicides are most preferred for the control of weeds in the cotton field of Turkey (PPP, 2019). These herbicides control some weeds before they reach the soil surface or when they exit, reducing the need for herbicides in the later development period. They move in the soil by rainfall, irrigation, and mechanical means can cling to the soil and provide weed-free areas. Moisture content is important for their activity in soil (Pala and Mennen 2017). Pendimethalin, trifluralin, fluometuron, and metolachlor are the most commonly applied herbicides for weed control in cotton before and/or before planting (Krutz et al., 2009; Charles et al., 2015; Pala and Mennan, 2018; PPP, 2019). There were some herbicides (trifloxysulfuron-sodium and pyrithiobac-sodium) to use after the emerging of cotton and weeds, it was known doubts regarding the use of these herbicides. It was important to investigate the effects of pre-plant and pre-emergence herbicide mixtures on weeds in cotton. Since cotton plants had a slower and longer life cycle compared to other plants, the risk of phytotoxicity to herbicides is high (Koger et al., 2007). For this reason, the effect of the active ingredients on the weeds as well as the effect on yield should be taken into consideration in the studies of herbicides (Streibig and Jensen 2000). This study focused on the efficiency and selectivity of tank mixes of clomazone with pre-plant and pre-emergence herbicides in cotton.

\section{Material and Method}

\subsection{Studied Location}

A field experiment was conducted in the cotton fields at Babahaki Village of Bismil district of Diyarbakir province in Southeast Anatolia region, in 2015 to study the effective weed management strategy with some pre-plant herbicides in cotton fields. Location of the trial field; $37^{\circ} 51^{\prime} 40.2^{\prime \prime} \mathrm{N} 40^{\circ} 46^{\prime} 29.6^{\prime \prime} \mathrm{E}$ with an altitude of $560 \mathrm{~m}$. Base fertilizer $0.5 \mathrm{t} \mathrm{ha}^{-1}$ compound super $(20.20 .0+\mathrm{Zn})$ preplanting soil preparation (mid-April), as the top fertilizer $0.2 \mathrm{t} \mathrm{ha}^{-1}$ urea before the first water (first week of June) and $0.2 \mathrm{t}$ ha ${ }^{-1}$ calcium ammonium nitrate (26\%) was used after the first irrigation (last week of June). Drip irrigation was performed 7 times for 24 hours with two weeks intervals. bollworm (Helicoverpa armigera), cotton leafworm (Spodoptera littoralis) and spiny bollworm (Earias insulana) against chlorrantraniliprole $200 \mathrm{~g} / 1$ SC 0.21 ha-1 insecticide spraying and against cotton seedling diseases (Soil origin fungi such as Rhizoctonia, Fusarium, Alternaria, Verticillium, Aspergillus, Pythium and Thielaviopsis) fertilization (seaweed, organic matter, trace elements).

The experiment was conducted on one of the most widely cultivated cotton cultivars Stoneville-468 in Diyarbakir, cultivated area. Cotton was sown in the first week of May to a depth of 3-5 cm between $72 \mathrm{~cm}$ inter row and $10 \mathrm{~cm}$ intra row. In the last week of April, before spraying, disinfestations were carried out at windless and calm hours of the day. Extreme weather conditions such as prolonged drought, heavy rainfall, late frost and hail were not observed during the trial period. During the application, the temperature was measured as $23^{\circ} \mathrm{C}$, relative humidity $52 \%$, wind speed $3.5 \mathrm{~km} \mathrm{~h}^{-1}(\mathrm{MS}, 2015)$.

\subsection{Experimental Design and Process}

Clomazone, fluometuron, oxyfluorfen and pendimethalin effective substances used in the experiment were given in Table 1. 
Table 1. Effective active ingredients used in cotton in Diyarbakir

\begin{tabular}{lllll}
\hline Herbicide* & Trade & Form & Dose** & Mode of action*** \\
\hline Clomazone & Titan & EC & 1.50 & $\begin{array}{l}13, \text { (Pigment inhibitor, Diterpene, F3, } \\
\text { Isoxazolidinone) }\end{array}$ \\
Fluometuron & Cottonex & SC & 2.00 & $\begin{array}{l}7 \text { (Photosynthesis inhibitor, } \\
\text { Photosystem II, C2, Urea) }\end{array}$ \\
Oxyfluorfen & Goal 4F & SC & 0.40 & $\begin{array}{l}14 \text { (Cell membrane disruptors, PPO, E, } \\
\text { Diphenylether) }\end{array}$ \\
Pendimethalin & Stomp Extra & CS & 3.00 & $\begin{array}{l}3 \text { (Seedling inhibitor, Microtubule, K1, } \\
\text { Dinitroaniline) }\end{array}$
\end{tabular}

* BKU (2017), **Dose $\left(1 \mathrm{ha}^{-1}\right)$, *** Mode of action according to HRAC (2019)

The field experiment was established with randomized block design with four replications. The herbicide mixture doses and the witness (weed-free parcel) included in the experiment constitute the characteristics of the experiment. The plots were kept at $4 \mathrm{~m} x$ $\mathrm{m}=20 \mathrm{~m}^{2} .1 \mathrm{~m}$ between the blocks and $0.5 \mathrm{~m}$ between the plots are left safety strip. The application was carried out with a sprayer with a spray arm operating at constant pressure ( $3 \mathrm{~atm})$ and a fan beam (TT-110.02) with multiple nozzles $(0.5 \mathrm{~m}$ between the ends) providing uniform distribution throughout the experiment field. Herbicide mixtures and ratios used in the experiment were given Table 2.

Table 2. List of treatments evaluated in cotton herbicide selectivity test in Diyarbakir

\begin{tabular}{clc}
\hline Treatments & Active ingredients of herbicides & Dose $\left(\mathbf{l} \mathbf{~ h a}^{-\mathbf{1}}\right)$ \\
\hline $\mathrm{T}_{1}$ & clomazone + oxyfluorfen & $0.20+0.25$ \\
$\mathrm{~T}_{2}$ & clomazone + oxyfluorfen & $0.30+0.25$ \\
$\mathrm{~T}_{3}$ & clomazone + oxyfluorfen & $0.40+0.25$ \\
$\mathrm{~T}_{4}$ & clomazone + oxyfluorfen & $0.20+0.30$ \\
$\mathrm{~T}_{5}$ & clomazone + oxyfluorfen & $0.20+0.35$ \\
$\mathrm{~T}_{6}$ & clomazone + pendimethalin & $0.20+1.50$ \\
$\mathrm{~T}_{7}$ & clomazone + pendimethalin & $0.30+2.00$ \\
$\mathrm{~T}_{8}$ & clomazone + pendimethalin & $0.40+1.50$ \\
$\mathrm{~T}_{9}$ & clomazone + fluometuron & $0.20+1.50$ \\
$\mathrm{~T}_{10}$ & clomazone + fluometuron & $0.30+2.00$ \\
$\mathrm{~T}_{11}$ & control & 0 \\
\hline
\end{tabular}

Since it was known that cotton germinates about 8 days after sowing (Salgado et al., 2002), herbicides were applied 3 days after sowing before the emergence (pre-emergence) and the effect $(\%)$ and selectivity $(\%)$ on the crops were investigated. Measurements were made in randomly selected areas of $1 \mathrm{~m}^{2}$. In order to prevent weed effect in the selectivity study, all plots were cleaned from weeds by hand weeding or tractor hoeing during the cotton production season. The weeds were specifically recorded using $1.0 \mathrm{~m} x 1.0$ $\mathrm{m}$ quadrate from three random locations on each plot. The weeds falling within the frames of the quadrat were collected, categorized into grasses and broad-leaved weeds, shade dried and later dried in the hot-air oven at $80^{\circ} \mathrm{C}$ for $72 \mathrm{~h}$. The total dry weight of grasses and broadleaved weeds recorded in $\mathrm{g} \mathrm{m}^{-2}$. Weed control efficiency (WCE, \%) of herbicides were made 14,28 and 56 days after herbicide application (DAT 14, DAT 28, and DAT 56) and the symptoms (yellowing, deformation, drying, etc.) of the weeds were clearly and accurately. The visual scale was evaluated between $0-100 \%(0 \%=$ no effect, $100 \%=$ complete weed control). Weights were determined by harvesting weeds in an area of $1 \mathrm{~m}^{2}$. WCE (\%) was calculated as per the procedure [1] given by Main et al. (2010).

$$
W C E(\%)=\frac{D W_{c}-D W_{t}}{D W_{c}} \times 100
$$

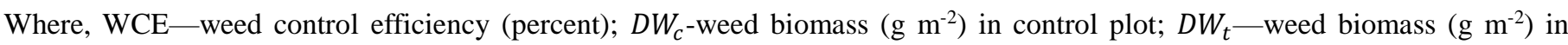
treated plot.

Crop injury (\%) were evaluated between 1 and $9(1=$ no damage, $9=$ complete plant death $)$ by the selectivity scale proposed by EWRC (1964) 7, 15 and 28 days after cotton germination (Puntener, 1981). All cultural processes, bollworm cotton leafworm, and spiny bollworm were tested, also defoliant were used. Thus, herbicide applications became the only variable. crop injury in this study plant height $(\mathrm{cm})$ and cotton yield $\left(\mathrm{t} \mathrm{ha}^{-1}\right)$ were investigated for each plot. Such these regarding agronomic characters, ten competitive plants were randomly selected from each plot and observations were recorded for growth and yield attributes. 


\subsection{Statistical Analysis}

The data obtained from each plot were calculated by converting it to decare. In the study, the values obtained for each feature, JMP 5.0.1. using the statistical package program; The averages were grouped according to the One-way ANOVA (Analysis of Variance) with LSMeans Tukey HSD (Honestly Significant Difference) test for comparing multiple treatments were determined.

\section{Result and Discussion}

After planting of cotton and weeds before germination were applied all herbicide mixtures. In the experiment field; Amaranthus albus L., A. retroflexus L., Chenopodium album L.., Chrozophora tinctoria (L.) Rafin., Convolvulus arvensis L, Cynodon dactylon (L.) Pers., Cyperus rotundus L., Datura stramonium L., Digitaria sanguinalis (L.) Scop., Echinochloa colonum (L.) Link., Echinochloa crus-galli (L.) P. Beauv., Heliotropium europaeum L., Hibiscus trionum L., Physalis angulata L., Solanum nigrum L., Sorghum halepense (L.) Pers., Tribulus terrestris L. ve Xanthium strumarium L. weed species were found. The effects of herbicide mixtures on weeds were found to be significant $(\mathrm{p}<0.05)$ in applications and replications in ANOVA. Important factors were subjected to Tukey test and applications are given in Table 3.

Table 3. Effectiveness of herbicide blends on weeds in cotton fields prior to emergence (\%)

\begin{tabular}{|c|c|c|c|c|c|c|}
\hline \multirow{2}{*}{ Treatments } & \multicolumn{6}{|c|}{ WCE $(\%)$} \\
\hline & 14. Days & EWRS & 28. Days & EWRS & 56. Days & EWRS \\
\hline $\mathrm{T}_{1}$ & $62.75^{\mathrm{e}}$ & Less & $68.25^{\mathrm{e}}$ & Less & $60.50^{\mathrm{h}}$ & Less \\
\hline $\mathrm{T}_{2}$ & $73.25^{\mathrm{d}}$ & Moderate & $68.13^{\mathrm{e}}$ & Less & $68.00^{\mathrm{g}}$ & Less \\
\hline $\mathrm{T}_{3}$ & $81.50^{\mathrm{c}}$ & Good & $82.25^{\mathrm{d}}$ & Good & $79.75^{\mathrm{f}}$ & Moderate \\
\hline $\mathrm{T}_{4}$ & $85.88^{\mathrm{b}}$ & Good & $82.38^{\mathrm{d}}$ & Good & $82.25^{\mathrm{e}}$ & Good \\
\hline $\mathrm{T}_{5}$ & $88.88^{\mathrm{ab}}$ & Good & $85.38^{\mathrm{cd}}$ & Good & $88.75^{\mathrm{d}}$ & Good \\
\hline $\mathrm{T}_{6}$ & $88.88^{\mathrm{ab}}$ & Good & $88.88^{\mathrm{bc}}$ & Good & $89.50^{\mathrm{d}}$ & Good \\
\hline $\mathrm{T}_{7}$ & $90.50^{\mathrm{a}}$ & Full & $89.38^{\mathrm{b}}$ & Good & $90.88^{c}$ & Full \\
\hline $\mathrm{T}_{8}$ & $91.25^{\mathrm{a}}$ & Full & $90.88^{\mathrm{b}}$ & Full & $92.00^{\mathrm{c}}$ & Full \\
\hline $\mathrm{T}_{9}$ & $91.75^{\mathrm{a}}$ & Full & $88.63^{\mathrm{bc}}$ & Good & $93.25^{\mathrm{b}}$ & Full \\
\hline $\mathrm{T}_{10}$ & $92.00^{\mathrm{a}}$ & Full & $95.00^{\mathrm{a}}$ & Full & $94.75^{\mathrm{a}}$ & Full \\
\hline $\mathrm{T}_{11}$ & $0.00^{f}$ & 0 & $0.00^{\mathrm{f}}$ & 0 & $0.00^{\mathrm{i}}$ & 0 \\
\hline
\end{tabular}

Differences between the means indicated by the same letter are not significant at $\mathrm{P}<0.05$ level

The effect of herbicide mixtures on weeds began to be seen during germination and emergence and according to the results of the analysis, their importance for all three observation periods were recorded. Accordingly, all the mixtures except clomazone + oxyfluorfen $(0.201+0.251)$, clomazone + oxyfluorfen $(0.301+0.251)$, clomazone + oxyfluorfen $(0.401+0.251)$ were found to provide efficacy in over $80 \%$ weed control. It was determined that clomazone + fluometuron $(0.301+21)$ mixture gave the best control (95\%). Pre-emergence herbicides require more precipitation for activation. The effectiveness of the mixtures on the weeds $\%$ may have been influenced by rainfall and the more regular rainfall regime on the day after planting. Furthermore, no mixture showed sufficient efficacy in Physalis angulata and Xanthium strumarium species.

The selectivity of the herbicides refers to the phytotoxicity (crop injury) caused by the product due to its mechanism of action (Cobb, 1992). It covers all the morphological and physiological symptoms that occur in the plant after the exposure of an herbicide to an herbicide. The selectivity of the herbicides is directly proportional to the uptake and transport of the active substances and inversely proportional to the detoxification. The results of visual product damage assessments 7,15 and 28 days after cotton germination are given in Table 4.

Table 4. Phytotoxicity (\%) formed in cotton by herbicide mixtures before emergence

\begin{tabular}{|c|c|c|c|c|c|c|}
\hline \multirow{2}{*}{ Treatments } & \multicolumn{6}{|c|}{ Crop Injury (\%) } \\
\hline & 7. Days & EWRS & 15. Days & EWRS & 28. Days & EWRS \\
\hline $\mathrm{T}_{1}$ & $3.74^{\mathrm{de}}$ & 1 & $5.86^{\mathrm{cd}}$ & 1 & $0.98^{\mathrm{cd}}$ & 1 \\
\hline $\mathrm{T}_{2}$ & $3.19^{\mathrm{ef}}$ & 1 & $6.81^{\mathrm{bc}}$ & 1 & $2.65^{\mathrm{bcd}}$ & 1 \\
\hline $\mathrm{T}_{3}$ & $4.94^{\mathrm{c}}$ & 1 & $5.84^{\mathrm{cd}}$ & 1 & $3.96^{\mathrm{bc}}$ & 1 \\
\hline $\mathrm{T}_{4}$ & $8.74^{\mathrm{b}}$ & 1 & $6.90^{\mathrm{bc}}$ & 1 & $5.51^{\mathrm{ab}}$ & 1 \\
\hline $\mathrm{T}_{5}$ & $10.05^{\mathrm{a}}$ & 2 & $17.28^{\mathrm{a}}$ & 2 & $7.8^{\mathrm{a}}$ & 1 \\
\hline $\mathrm{T}_{6}$ & $3.14^{\mathrm{ef}}$ & 1 & $6.33^{\mathrm{cd}}$ & 1 & $1.81^{\mathrm{de}}$ & 1 \\
\hline
\end{tabular}




\begin{tabular}{ccccccc}
\hline $\mathrm{T}_{7}$ & $4.31^{\mathrm{cd}}$ & 1 & $5.26^{\mathrm{cd}}$ & 1 & $3.23^{\text {cde }}$ & 1 \\
$\mathrm{~T}_{8}$ & $3.66 \mathrm{~d}^{\mathrm{ef}}$ & 1 & $8.61^{\mathrm{b}}$ & 1 & $1.50^{\text {cde }}$ & 1 \\
$\mathrm{~T}_{9}$ & $3.36 \mathrm{~d}^{\mathrm{ef}}$ & 1 & $4.68^{\mathrm{d}}$ & 1 & $0.10^{\mathrm{de}}$ \\
$\mathrm{T}_{10}$ & $2.61^{\mathrm{f}}$ & 1 & $5.65^{\mathrm{cd}}$ & 1 & $2.91^{\mathrm{bcd}}$ \\
$\mathrm{T}_{11}$ & $0.00^{\mathrm{g}}$ & 1 & $0.00^{\mathrm{e}}$ & 1 & $0.00^{\mathrm{e}}$ \\
\hline
\end{tabular}

Differences between the means indicated by the same letter are not significant at $\mathrm{P}<0.05$ level

In ANOVA, applications and repetitions were significant ( $\mathrm{p}<0.05) .11$ days after cotton planting cotton was seen to exit. All treatments except control caused crop injury to cotton plants and at 7, 15 and 28 days after cotton germination, symptoms of varying concentrations of fe toxicity appeared in the cotyledon, 2-4 and 4-6 leaf periods, respectively.

Applications in the 7 th day observations of phytotoxicity ( $T_{1}$ ef, $T_{2}$ ef, $T_{3} c, T_{4} b, T 5, T_{6}$ ef, $T_{7}$ cd, $T_{8}$ def, $T_{9}$ def, T10, $T_{11} g$ ) and replication $(1,4 \mathrm{a}, 2 \mathrm{~b}, 3 \mathrm{~b})$ were also statistically significant $(\mathrm{p}<0.05)$. Levels that are not interconnected by the same letter are significantly different. On the seventh day, clomazone + oxyfluorfen mixtures $(0.201+0.351)$ caused the highest levels of crop injury. Phytotoxicity of the oxyfluorfen active ingredient in PPO (Protoporphyrinogen oxidase) inhibitor diphenyl ether group was similar to the injuries seen in the cell membrane structure necrosis in cotton cotyledons of this mixture (Yamashita et al, 2008). Clomazone + fluometuron $(0.201+1.501)$ caused low crop injury and was identified as the most selective of the tested.

The difference between the applications $\left(\mathrm{T}_{1} \mathrm{~cd}, \mathrm{~T}_{2} \mathrm{bc}, \mathrm{T}_{3} \mathrm{~cd}, \mathrm{~T}_{4} \mathrm{bc}, \mathrm{T} 5, \mathrm{~T}_{6} \mathrm{~cd}, \mathrm{~T}_{7} \mathrm{~cd}, \mathrm{~T} 8, \mathrm{~T}_{9} \mathrm{~d}, \mathrm{~T}_{10} \mathrm{~cd}, \mathrm{~T}_{11} \mathrm{e}\right)$ in both years of the experiment was also statistically significant. It was found. On day 15 , clomazone + oxyfluorfen mixtures $(0.201+0.351)$ caused the highest levels of crop injury. Clomazone + fluometuron $(0.201+1.501)$ caused minimal crop injury. All results determined on day 15 were found to be lower than the 15 th day damage symptoms (> 20\%) of the active substances diuron $\left(0.93 \mathrm{~kg} \mathrm{ha}^{-1}\right)$ and alachlor $(2.5$ $\mathrm{kg} \mathrm{ha}^{-1}$ ) by Siqueri (2002).

Applications on the 28th day observations of phytotoxicity in the experiment (T1 T1, T2, T3, T 4 f, T5, T6, T7, T8, T9, T10 1, T 11 k) and repeats (1 a, 2 b, 3 c, 4 d) was also statistically significant. On the twenty-eighth day, phytotoxicity in the 1st, 8th and 9th applications was almost lost. Freitas et al (2006), metolachlor-S effective substance in cotton after a period of crop injury and phytotoxicity of herbicides can be passed to support the detection of the heart can be reduced or can pass. Although the cotton plant was able to overcome the damages caused by the said herbicide mixtures, only the clomazone + oxyfluorfen mixtures $(0.201+0.351)$ had significant phytotoxicity $(7.89 \%)$ on day 28 . However, the product $\mathrm{ED}_{10}$ value is not more than $10 \%$.

When the data on the selectivity of herbicidal mixtures in the plant were evaluated, it was observed that the mixtures made with clomazone active ingredient had little effect on the carotenoid biosynthesis of cotton (especially mixture applications 4 and 5). However, new vivid, yellow and green pigments have emerged. Since oxyfluorfen has both leaf and soil activity, it has caused burn spots and spots on cotton leaves and also causes tanning and yellowing in the overall appearance of the plant. The highest phytotoxicity was determined in the mixture applications with this active ingredient (4th application 5.51\% and 5th application 7.89\%). Pendimethalin mixtures, although a little weakening in root development, shortening and thickening of the lateral roots were noticeable. This was felt by the poor coverage of the cotton and slightly deformed at the top of the plant in the 7th mixture (3.23\%). Fluometuron mixtures have little effect on the chlorophyll of the cotton. It is understood from the slight yellowing and bronzing of the leaf edge (10th application $2.91 \%$ ). Cotton roots were examined under microscope after cleaning in the laboratory, but no direct damage was seen. The most promising selectivity was obtained from clomazone $0.201+$ fluometuron 1.501 mixture $(0.10 \%)$. The effect of pre-emergence herbicide mixtures used in cotton experiment on cotton plant height and mass yield of cotton is given in Table 5.

Table 5. Effect of plant herbicides on plant height and yield before weaning $\left(\mathrm{t} \mathrm{ha}^{-1}\right)$

\begin{tabular}{ccc}
\hline Treatments & Plant length (cm) & Cotton yield (t ha-1) \\
\hline $\mathrm{T}_{1}$ & $66.41^{\mathrm{abcd}}$ & $4.82^{\mathrm{bc}}$ \\
$\mathrm{T}_{2}$ & $65.7^{\mathrm{bcd}}$ & $4.88^{\mathrm{abc}}$ \\
$\mathrm{T}_{3}$ & $63.9^{\mathrm{cd}}$ & $4.74^{\mathrm{c}}$ \\
$\mathrm{T}_{4}$ & $68.76^{\mathrm{abc}}$ & $4.78^{\mathrm{c}}$ \\
$\mathrm{T}_{5}$ & $62.38^{\mathrm{d}}$ & $4.72^{\mathrm{c}}$ \\
$\mathrm{T}_{6}$ & $65.51^{\mathrm{bcd}}$ & $4.94^{\mathrm{abc}}$ \\
\hline
\end{tabular}




\begin{tabular}{ccc}
\hline $\mathrm{T}_{7}$ & $71.45^{\mathrm{ab}}$ & $4.96^{\mathrm{abc}}$ \\
$\mathrm{T}_{8}$ & $65.55^{\mathrm{bcd}}$ & $4.84^{\mathrm{abc}}$ \\
$\mathrm{T}_{9}$ & $71.91^{\mathrm{a}}$ & $5.05^{\mathrm{ab}}$ \\
$\mathrm{T}_{10}$ & $64.95^{\mathrm{cd}}$ & $5.08^{\mathrm{a}}$ \\
$\mathrm{T}_{11}$ & $54.85^{\mathrm{e}}$ & $3.33^{\mathrm{d}}$
\end{tabular}

\section{Differences between the means indicated by the same letter are not significant at $\mathrm{P}<0.05$ level}

The difference between the applications (abcd, $\mathrm{T}_{2} \mathrm{bcd}, \mathrm{T}_{3} \mathrm{~cd}, \mathrm{~T}_{4} \mathrm{abc}, \mathrm{T}_{5} \mathrm{~d}, \mathrm{~T}_{6} \mathrm{bcd}, \mathrm{T} 7 \mathrm{abs}, \mathrm{T}_{8} \mathrm{bcd}, \mathrm{T} 9, \mathrm{~T}_{10} \mathrm{~cd}, \mathrm{~T}_{11} \mathrm{e}$ ) was also found to be statistically significant $(\mathrm{p}<0.05)$. ). Levels that are not interconnected by the same letter are significantly different. The lowest plant height was determined in the control plot $(54.85 \mathrm{~cm})$. It was found that clomazone $0.201+$ oxyfluorfen 0.351 mixture significantly decreased cotton plant height $(62.38 \mathrm{~cm})$. It was observed that cotton plant height ranged between $55-72 \mathrm{~cm}$.

The difference between the applications ( $T_{1} b c, T_{2} a b c, T_{3} c, T_{4} c, T_{5} c, T_{6} a b c, T_{7} a b c, T_{8}$ abc, $T 9$ abs, $\left.T 10, T_{11} d\right)$ was found to be statistically significant $(\mathrm{p}<0.05)$. . Levels that are not interconnected by the same letter are significantly different. Dan et al (2011) Clomazone + oxyfluorfen $(1.00+0.19 \mathrm{~kg}$ ha-1) in the cotton $12.8-13.5 \%$, yield loss of yield, the study that we do in this study compared to other applications of this mixture application yields up to $0.36 \mathrm{t} \mathrm{ha}^{-1}$ determination of yield reduction. supports.

\section{Conclusion}

The development and production of transgenic cotton varieties tolerant to herbicides in our country are not allowed. Therefore, various tactics for the control of weeds, which are problematic, need to be researched, developed and expanded. Since it is known that different herbicides alone are insufficient in cotton fields, the effect of tank mixes of herbicides at different rates on weeds, yield and yield were investigated in ST 468 cotton variety in Diyarbakir. Clomazone 0.201 ha- 1 + fluometuron 1.501 ha-1, clomazone 0.301 ha$1+$ fluometuron 2.001 ha-1, clomazone 0.401 ha- 1 + pendimethalin 1.501 ha- 1 and clomazone 0.301 ha- $1+$ pendimethalin 2.001 ha1 mixtures was found to be complete weed control efficiency, respectively. This result showed that mixtures with clomazone active ingredient increase the efficiency of herbicides pre-planting. The riskiest crop injury in terms of crop selectivity was observed in oxyfluorfen mixtures. The highest cotton yield (> $5 \mathrm{t}$ ha-1) was obtained from the application of mixtures of clomazone 0.301 ha- $1+$ fluometuron 2.001 ha- 1 and clomazone 0.201 ha-1 + fluometuron 1.501 ha-1, respectively. One of the important aspects of using preemergence herbicide mixtures is that it is an alternative method that can help prevent the spread of weeds resistant to glyphosate in recent years. In the study, it was concluded that clomazone and fluometuron effective herbicides can be used as a mixture for the control of weeds in cotton before emergence.

\section{References}

Berger, S. T., Ferrell, J. A., Rowland, D.L., Webster, T. M. (2015). Palmer amaranth (Amaranthus palmeri) competition for water in cotton. Weed Sci., 63, 928-935. https://doi.org/10.1614/WS-D-15-00062.1

Bukun, B. (2004). Critical periods for weed control in cotton in Turkey. Weed Res., 44, 404-412. https://doi.org/10.1111/j.1365$\underline{3180.2004 .00415 . x}$

Cobb A. H., Reade P. H. (2011). Herbicides and Plant Physiology. 2nd edn., Wiley-Blackwell: A John Wiley \&Sons, Chichester, UK.

Dan, H. A., Barroso, A. L. L., Oliveıra, Jr R. J., Constantin, J., Dan, L. G. M., Braz, G. B. P., Oliveıra-Neto, A. M. and D‘avila, R. P. (2011). Selectivity of clomazone applied alone or in tank mixtures to cotton, Planta Daninha, 29(3), 601-607. http://dx.doi.org/10.1590/S0100-83582011000300014

Economou, G., Bilalis, D., Avgoulas, C. (2005). Weed flora distribution in Greek cotton fields and its possible influence by herbicides. Phytoparasitica, 33, 406-419. https://doi.org/10.1007/BF02981309

EDIS. (2019). University of Florida IFAS Extension by Wright, D.L., Small, I and Martinil, X.. Production of ultra-narrow-row cotton. Original publication date August 2000. Revised July 2011 and November 2018. [accessed on: 05 Nov. 2019] Available at: https://edis.ifas.ufl.edu/aa267.

EWRC. 1964. Report of $3^{\text {rd }}$ and $4^{\text {th }}$ meetings of EWRC (European Weed Research Council) - Committee of Methods in Weed Research. Weed Res., 4(1), 88.

Freitas, R. S., Berger, P. G., Ferreira, L. R., Silva, A. C., Cecon, P. R., Silva, M. P. (2006). Weed management of cotton under notillage. Planta Daninha, 20(2), 197-205. http://dx.doi.org/10.1590/S0100-83582006000200017

HRAC. (2019). Herbicide Resistance Action Committee. [accessed on: 19 Apr. 2019] Available at: https://hracglobal.com/

Koger, C. H. (2007). Effect of residual herbicides used in the last post-directed application on weed control and cotton yield in glyphosate- and glufosinate-resistant cotton. Weed Technol., 21(2), 378-383. https://doi.org/10.1614/0890$\underline{037 \mathrm{X}(2007) 21[378: \mathrm{EORHUI}] 2.0 . \mathrm{CO} ; 2}$ 
Kraehmer, H. (2016). Atlas of weed mapping. John Wiley \& Sons, Inc, Wiley-Blackwell, New York USA.

Kruger, G. R., Johnson, W. G., Weller, S. C., Owen, M. D. K., Shaw, D. R., Wilcut, J. W., Jordan, D. L., Wilson, R. G., Bernards, M. L., Young. B. G. (2009). US grower views on problematic weeds and changes in weed pressure in glyphosate resistant corn, cotton, and soybean cropping systems. Weed Technol. 23, 162-166. https://doi.org/10.1614/WT-08-040.1

Krutz, L. J., Locke, M. A., Steinriede, R. W. (2009). Interactions of tillage and cover crop on water, sediment, and pre emergence herbicide loss in glyphosate-resistant cotton: implications for the control of glyphosate-resistant weed biotypes. J. Environ. Qual., 38(3), 1240-1247. https://doi.org/10.2134/jeq2008.0342

Main, C. L., Michael, A. S., Murdock, E. C. (2007). Weed response and tolerance of enhanced glyphosate resistant cotton to glyphosate. J. Cotton Sci., 11(2), 104-109.

Memon, R. S., Bhatti, G. R., Khalid, S., Ahmed, S. (2014). Illustrated weed flora of cotton crop of Khairpur district, Sindh. Pak. Pak. J. Bot., 46, 5-12.

MS. (2015). Meteorological Service. [accessed on: 27 Jun. 2015] Available at: https://www.mgm.gov.tr/

Nalini, K., Muthukrishnan, P., Chinnusamy, C., Vennila, C. (2015). Weeds of cotton-A Review. Agricultural Reviews, 36(2). https://doi.org/10.5958/0976-0741.2015.00016.1

Ortiz, C.E., Bourland, F. M. (1999). Comparative early growth of cotton seedlings expressing a visible true leaf at emergence and normal phenotype seedlings. J. Agric. Univ. P. R., 83, 19-31.

Pala, F., Mennan, H. (2014). Investigation of trifluralin resistance in some species of pigweed (Amaranthus spp.) in cotton fields of the Southeastern Anatolia Region. Turkish Journal of Weed Science, 17(1), 1-8.

Pala, F., Mennan, H. (2016). Determination of pigweed (Amaranthus spp.) species and their frequency and density in cotton fields in Southeastern Anatolia Region, Turkey. Journal of Agricultural Faculty of Mustafa Kemal University, 21(2), 139-148.

Pala, F., Mennan, H. (2017). Weed control methods in cotton fields of Diyarbakir. International Conference on Agriculture, Forest, Food Sciences and Technologies, 15-17 May, Cappadocia, Turkey.

Pala, F., Mennan, H. (2018). Current state of weed management and problematic weeds in cotton fields of Diyarbakir. Journal of Agriculture Faculty of Ege University, 55(1), 111-117. https://doi.org/10.20289/zfdergi.330081

Papamichail, D., Eleftherohorinos, I., Froud-Williams, R., Gravanis, F. (2002). Critical periods of weed competition in cotton in Greece. Phytoparasitica, 30, 105-111. https://doi.org/10.1007/BF02983976

PPP. (2019). Plant Protection Products. [accessed on: 01 May. 2019] Available at: https://bku.tarim.gov.tr/

Puntener, W. (1981). Manual for field trials in plant protection. Second Edition. Ciba-Geigy Limited, Basle, Switzerland.

Salgado, T. P., Alves, P. I. C. A, Mattos, E. D., Martins, J. F., Hernandez, D. D. (2002). Weed interference periods in the cotton crop (Gossypium hirsutum). Planta Daninha, 20(3), 373-379. http://dx.doi.org/10.1590/S0100-83582002000300007

Siqueri, F., V. (2002). Controle de ervas daninhas em pré-emergência. Boletim de Pesquisa de Algodão. Fundação de Apoio à Pesquisa Agropecuária. Mato Grosso, 8p.

Streibig, J. C., Jensen, J. E. (2000). Actions of herbicides in mixtures. In Herbicides and their mechanisms of action (pp. 152-180). CRC Press, Sheffield, UK.

Walker, S. R., Taylor, I. N., Milne, G., Osten, V. A., Hoque, Z., Farquharson, R. J. (2005). A survey of management and economic impact of weeds in dryland cotton cropping systems of subtropical Australia. Aust. J. Exp. Agric., 45, 79-91. https://doi.org/10.1071/EA03189

Yamashita, O. M., Mendonça, F. S., Orsi, J. V. N., Resende, D. D., Kappes, C., Guımarães, S. C. (2008) Effect of reduced oxyfluorfen rates on cotton cultivars. Planta Daninha, 26(4), 917-921. http://dx.doi.org/10.1590/S0100-83582008000400024

Zhang, Z. P. (2003). Development of chemical weed control and integrated weed management in China. Weed Biol. Manag., 3, 197203. https://doi.org/10.1046/j.1444-6162.2003.00105.x 